\title{
Determinants of Manufacturing Firms' Financial Performance in Pakistan
}

\author{
DR. SAID SHAH \\ Assistant Professor/Head, Department of Management Sciences \\ University of Swabi, KP, Pakistan \\ saidshah64@yahoo.com \\ S.M. AMIR SHAH \\ Associate Professor/Head, Department of Commerce \\ Allama Iqbal Open University, Islamabad, Pakistan
}

\begin{abstract}
Investment in working capital by and large shows better returns than investment in fixed assets. As such proper management of working capital rightfully attracts a lot of attention. The objective of this research is to examine the impact of size and working capital management efficiency on firms' financial performance using 10 years (20042013) secondary data of 153 firms listed on Pakistan Stock Exchange and employing regression and ratio analyses. Results show that performance-wise large firms are better whereas WCME-wise small and medium firms are better. These findings indicate that better performance of large firms is not because of efficient utilization of working capital - rather it may be due to some other factors and these firms can further improve their performance if working capital is managed more efficiently.
\end{abstract}

Keywords: Firms' performance, Firms' size, Market capitalization, Working capital management efficiency

\section{Introduction}

The importance of working capital may be found in the common practice being observed by suppliers of raw material and providers of credit who prefer to develop relationships with firms having the capacity and capability of timely meeting their short term obligations. On the other hand, firms maintaining low working capital to total assets ratios usually face serious cash flow problems and are unable to honor their short term liabilities despite earning high profits. Based on the nature of product, a major part of firms' resources are invested in short term assets. Certain industries like fertilizer and steel factories may have a high level of fixed assets and a lesser level of current assets however most of the consumer goods manufacturers have quite somewhat high percentage of their total assets held in the form of current assets. For example as per the data obtained from State Bank of Pakistan for 2004-13, average receivables are 11.91\%, inventory $10.95 \%$ and payables $20.48 \%$ of total assets in (non-financial) corporate sector of Pakistan. Because of the volume of investment in current assets and quantum of current liabilities, effective and efficient working capital management (WCM) practices warrant greater attention from firms of all sizes. WCM indicates maintaining a healthy balance among current assets and liabilities with a view to maximize profit and improve 
earnings per share. Because of huge investment in short term assets and liabilities, WCM has a significant impact on a firm's profitability (Deloof 2003). Fairly high variations are expected in the working capital management efficiency (WCME) and performance of firms due to their sizes. Larger firms must be technically, professionally, and size-wise stronger than small and medium firms to avail the benefits of scale economies. Due to their financial power, large firms significantly influence economies of their respective countries. This is also true in case of Pakistan where a large number of such firms operate (31.37\% of the sample used in this study are large firms). This study, besides investigating the impact of WCME, also presents a comparison of financial performance among small, medium and large firms.

Theoretical base regarding liquidity maintenance can be found in Operating Cycle Theory (Park \& Gladson, 1963), Agency Theory (Jensen \& Meckling, 1976), Financing Theory (Emery, 1987) and Liquidity Theory (Nielson, 2002). Operating cycle theory advocates calculation of working capital requirements on the basis of "natural business year'. According to agency theory, managers of large firms may prefer keeping higher level of working capital for operational convenience whereas in small firms their preference is for low levels of working capital. Lower levels of working capital mean lower financial costs but they demand greater management attention to keep the firm fully functional. On the other hand, higher level of working capital may mean lower profits due to less efficient use of current assets but they pose lesser strain on managers. In other words, agents may sacrifice a part of the profit (that belongs to principals) for the sake of their own convenience. Financing theory states that firms with greater probability of default prefer trade credit instead of cash loan from financial institutions. According to liquidity theory, firms having credit constraints (i.e. inability to raise cash loans from financial institutions) prefer trade credit which is avoided by firms having easy approach to cash credit. Easy access to trade credit reduces firms' dependence on cash financing of working capital through external sources. Working capital being an integral part of long term funds invested in current assets depends on the preference order of managers while selecting means of financing current assets. This is also advocated by(Myers \& Mailuf,1984).

\section{Literature Review}

Fama and French (1992) used market capitalization (MC) as measure of portfolio size and found its strong positive relation with average returns. Majumdar (1997) found that older firms are more productive and less profitable, whereas larger firms are more profitable and less productive. Connor and Sehgal (2001) examined the impact of market, size and book to market ratio on stock returns using multivariate regression analysis and found that all these three factors (market, size and book to market ratio) explain stock returns. Dalbor, Kim and Upneja (2004) used number of owners, number of employees, age of firm, natural log of sales and natural log of assets as proxies of firms' size and examined their impact on volume of debt used by different firms. Number of owners is found to be the most significant variable to explain dependent variable. Du and Girma (2009) investigated the relationship between firm size and financial structure using number of employees as firms' size and found that financing source influence growth more in small firms as compared to large firms. They further found that internally 
generated funds are more effective for promoting small firms and external finance is effective for large firms.

Ogundipe, Idowu and Ogundipe (2012) analyzed WCME among selected small and medium enterprises using regression analysis and found that small firms having weak liquidity position have to rely on credit facility and become insolvent, due to their weak financial performance and poor record keeping system. According to Zaremba and Konieczka (2015), the impact of illiquidity and transaction costs on value and size of firms is fatal in Central and Eastern European Countries' stock markets.

The available research investigating the impact of firms' size on WCME and financial performance is inadequate. Smith, (1973) found that the primary reason behind business failures is inappropriate use of the WCM techniques. Richards and Laughlin (1980) advocated CCC as a base for determining the actual working capital requirements of a firm. Deloof (2003) found that a firm value can be increased by reducing days receivable and taking long to pay their creditors. Gentry, Vaidyanathan and Lee (1990) investigated short term investments of firms by using weighted cash conversion cycle (WCCC) calculated as weighted operating cycle (WOC) minus weighted payable effect. They found that the larger the volume of investment in raw material and work in process, the longer the weighted operating cycle and vice versa. They further found that the larger the payable weight, the greater the deferral of payment to the suppliers and the shorter the weighted cash conversion cycle. This shows a positive relationship between inventory period and WOC and negative relationship between payment period and WCCC leading to a positive relationship between WCCC and firms' performance. Teruel and Solano (2007) found a negative relationship between average collection period and profitability of firms.

Previous studies indicate lack of adequate scientific research on investigating the impact of firms' size on WCME and ultimately profitability. These studies are more or less country specific as such may not have a general applicability. What financially and operationally sound firms do to manage their working capital which weak firms do not do and vice versa leading to variation in WCM practices. By finding and analyzing these factors, weak firms can learn a lot which can make them successful. The study uses CCC as comprehensive variable to measure WCME. The shorter the CCC, the higher will be firms' WCME which will lead to higher firms' profits. This study explores which size of firms' (small, medium or large) WCM practices is better besides determining the impact of size on profitability testing the following hypotheses:

Hypothesis 1: There is a positive relationship between firms' size and performance.

Hypothesis 2: Small firms are more efficient in utilizing WCME than larger firms.

\section{Data}

Data set includes 153 firms listed on Pakistan Stock Exchange covering a period of ten years (2004-2013) for ten economic groups namely textiles, sugar, chemicals \& pharmaceuticals, fuel \& energy, autos \& engineering, fast moving consumer goods (FMCGs) \& foods, cement, paper \& board, tobacco and jute. The sample does not include financial firms. The sample also excludes firms the industrial average (IA) of which is not available. Thus a panel data set of 1,530 firm-year observations has been obtained from State Bank of Pakistan's document "Balance Sheet Analysis" and published annual reports of firms. Sample is selected on disproportionate stratified 
random sampling basis. Data is arranged and presented in pooled form combining time series and cross sectional observations. Time series in the study presents year wise determination of WCME and firm's performance measured by calculating various ratios for 10 years from 2004 to 2013 while cross sectional data covers determination of WCME and firm's performance measured by calculating various ratios separately for each year under review. Stratification is an efficient research design providing more information with a given sample size, as such used to meet the assessment requirements of each stratum in the universe. Industry-wise distribution of sample firms is given in table 1 .

Table 1: Industry-Wise Distribution of Sample Firms

\begin{tabular}{lcccc}
\hline Industry & Small & Medium & Large & All firms \\
\hline Textiles & 20 & 13 & 2 & 35 \\
Sugar & 8 & 8 & 0 & 16 \\
Chemicals & 10 & 10 & 8 & 28 \\
Fuel and Energy & 0 & 5 & 14 & 19 \\
Engineering & 2 & 11 & 7 & 20 \\
FMCGs & 0 & 4 & 6 & 10 \\
Cement & 0 & 7 & 7 & 14 \\
Paper and Board & 3 & 1 & 2 & 6 \\
Tobacco & 1 & 0 & 2 & 3 \\
Jute & 2 & 0 & 0 & 2 \\
\hline Total firms & 46 & 59 & 48 & 153 \\
\hline
\end{tabular}

\subsection{Variables in the Study}

The details of dependent, independent, and control variables are given in table 2 below:

Table 2: Variables

\begin{tabular}{|c|c|c|}
\hline $\begin{array}{l}\text { Variable } \\
\text { Type }\end{array}$ & Variable & Calculations \\
\hline Dependent & $\begin{array}{l}\text { Return on assets (ROA), a } \\
\text { measure of profitability in } \\
\text { relationship with total } \\
\text { assets/investment }\end{array}$ & Net profit divided by total assets \\
\hline Independent & $\begin{array}{l}\text { Market capitalization (MC) } \\
\text { representing firms' size } \\
\text { CCC, used as a comprehensive } \\
\text { measure of WC management } \\
\text { efficiency (Deloof, 2003) } \\
\text { Inventory turnover in days } \\
\text { (ITDs) } \\
\text { Receivable turnover in days } \\
\text { (RTDs), } \\
\text { Payable turnover in days (PTDs) }\end{array}$ & $\begin{array}{l}\text { Number of outstanding shares } \\
\text { multiplied by market price per share } \\
\text { (Inventory turnover in days }+ \\
\text { Receivable turnover in days) }- \\
\text { Payable turnover in days } \\
\text { (Inventory } \div \text { Cost of goods sold) } \mathrm{x} \\
365 \\
\text { (Receivables } \div \text { Sales) x } 365 \\
\text { (Payables } \div \text { Purchases) x } 365\end{array}$ \\
\hline Control & SG & $\begin{array}{l}\text { (current year's sales - previous year's } \\
\text { sales)/ previous year's sales }\end{array}$ \\
\hline Shah \& Shah & 4 & ISSN: $2520-0739$ \\
\hline
\end{tabular}




\section{Analysis}

\subsection{Descriptive Analysis}

As detailed in Table 3, average RoA of small, medium and large firms is $2.76 \%$, $7.43 \%$ and $16.92 \%$ respectively showing highest performance of large firms. A narrow range between mean and standard deviation of RoA in large firms indicate stable profits in these firms. Average CCC of small and medium firms is 50.75 days whereas that of large firms 31.65 days. These compared with standard deviations of 191.54 for small, 146.56 for medium and 106.91 for large firms shows high variability in working capital management efficiencies. However size of CCC indicates efficient utilization of working capital by large firms. At an average, small firms take 122.55 days, medium 97.23 days and large firms 101.71 days to convert their inventory into finished goods. On average, small firms allow a credit period of 47.15 days, medium firms 41.52 days and large firms 45.27 days to their customers. Small firms take a longest period of 117.62 days to make payment to their suppliers followed by medium firms taking 91.19 days and large firms 70.03 days. As such medium firms are efficient in terms of inventory conversion and credit recovery whereas small firms are efficient to avail a longer period to utilize suppliers' funds. Average sales growth is $24 \%$ for small and $20 \%$ for medium and large firms.

Table 3: Descriptive Statistics

\begin{tabular}{clcccc}
\hline Variable & Size & Mean & Standard Error & Median & $\begin{array}{c}\text { Standard } \\
\text { Deviation }\end{array}$ \\
\hline \multirow{2}{*}{ RoA } & Small & 2.76 & 0.76 & 1.43 & 16.39 \\
& Medium & 7.43 & 0.50 & 6.17 & 12.39 \\
& Large & 16.92 & 0.73 & 13.82 & 15.70 \\
\hline \multirow{2}{*}{ MC } & Small & 46.54 & 16.85 & 0.00 & 361.01 \\
& Medium & 23.87 & 3.75 & 3.55 & 92.62 \\
& Large & 31.01 & 5.82 & 11.59 & 124.85 \\
\hline \multirow{2}{*}{ CCC } & Small & 50.75 & 8.93 & 64.91 & 191.54 \\
& Medium & 50.75 & 5.93 & 65.97 & 146.56 \\
& Large & 31.65 & 4.98 & 17.65 & 106.91 \\
\hline \multirow{2}{*}{ ITDs } & Small & 122.55 & 6.76 & 84.75 & 145.08 \\
& Medium & 97.23 & 4.43 & 80.50 & 109.38 \\
& Large & 101.71 & 13.75 & 41.23 & 294.96 \\
\hline \multirow{2}{*}{ RTDs } & Small & 47.15 & 5.20 & 26.31 & 111.52 \\
& Medium & 41.52 & 2.59 & 23.90 & 63.86 \\
& Large & 45.27 & 3.37 & 14.66 & 72.28 \\
& & & & & ISSN: $2520-0739$
\end{tabular}




\begin{tabular}{clcccc}
\hline \multirow{2}{*}{ PTDs } & Small & & & & \\
& Medium & 117.62 & 10.44 & 52.83 & 223.91 \\
& Large & 70.03 & 3.47 & 52.46 & 74.36 \\
\hline \multirow{2}{*}{ SG } & Small & 0.24 & 0.04 & 0.13 & 0.85 \\
& Medium & 0.20 & 0.03 & 0.14 & 0.77 \\
& Large & 0.20 & 0.03 & 0.16 & 0.54 \\
\hline
\end{tabular}

\subsection{Correlation Analysis}

Correlation analysis reported in Table 4 shows positive and significant relationship between CCC and RoA which contradicts the results of previous studies (Gentry, Vaidyanathan \& Lee, 1990; Teruel \& Solano, 2007; Ogundipe, Idowu and Ogundipe, 2012). This is due to high inefficient working capital utilization by overall Pakistani corporate sector (an efficient and non efficient ratio of 25:75). We further investigated the relationship of CCC components (ITDs, RTDs and PTDs) with RoA and found a strong negative relationship between PTDs and RoA which contradicts the finding of Deloof (2003) and indicates that the main inefficiency lies in availing trade credit in the form of payables.

Table 4: Correlations among Variables

\begin{tabular}{lrrrrrrr}
\hline Variables & \multicolumn{1}{l}{ RoA } & \multicolumn{1}{c}{ MC } & CCC & \multicolumn{1}{c}{ ITDs } & \multicolumn{1}{l}{ RTDs } & \multicolumn{1}{c}{ PTDs } & \multicolumn{1}{c}{ SG } \\
\hline RoA & 1 & .013 & $.069^{* *}$ & $-.051^{*}$ & $-.060^{*}$ & $-.176^{* *}$ & .049 \\
MC & .013 & 1 & .009 & .014 & -.006 & -.005 & .003 \\
CCC & $.069^{* *}$ & .009 & 1 & $.108^{* *}$ & $.170^{* *}$ & $-.621^{* *}$ & -.039 \\
ITDs & $-.051^{*}$ & .014 & $.108^{* *}$ & 1 & $.156^{* *}$ & $.276^{* *}$ & $-.061^{*}$ \\
RTDs & $-.060^{*}$ & -.006 & $.170^{* *}$ & $.156^{* *}$ & 1 & $.369^{* *}$ & .026 \\
PTDs & $-.176^{* *}$ & -.005 & $-.621^{* *}$ & $.276^{* *}$ & $.369^{* *}$ & 1 & .002 \\
SG & .049 & .003 & -.039 & $-.061^{*}$ & .026 & .002 & 1 \\
\hline
\end{tabular}

\subsection{Multivariate Analysis}

In this section, panel diagnostic tests and models used for multivariate analysis are presented. In order to bring conformity in results, pooled OLS model having the benefit of covering dummies as well as all those variables included in fixed effects model is used. The following model is used separately to estimate the results for small, medium and large firms:

$\operatorname{RoA}_{\mathrm{it}}=\beta_{0}+\beta_{1}(\mathrm{MC})+\beta_{2}(\mathrm{CCC})+\beta_{3}(\mathrm{ITDs})+\beta_{4}(\mathrm{RTDs})+\beta_{5}(\mathrm{PTDs})+\beta_{6}(\mathrm{SG})+\varepsilon$

Multicollinearity is checked using tolerance values. Previous studies indicate that data having tolerance value less than 2 have no problems of multicollinearity (for example Robert, 2007). Tolerance values for the data used in this study are well below the required levels for all variables (table 5), as such no multicollenearity problem exists. Park test (Park, 1966) is used to check heteroscedasticity in all regressions. Based on the results of Cumulative Sum (CUSUM) recursive coefficients test (test used to check model stability), the model used for estimating the results is stable 
Table 5: Tolerance Values

\begin{tabular}{lcccccc}
\hline Segment & MC & CCC & ITDs & RTDs & $\begin{array}{c}\text { PTD } \\
\text { s }\end{array}$ & SG \\
\hline Small firms & 0.997 & .106 & .229 & .230 & .080 & 0.933 \\
Medium firms & .991 & .267 & .447 & .472 & .140 & .983 \\
Large firms & .974 & .529 & .886 & .575 & .572 & .985 \\
\hline
\end{tabular}

\subsection{Regression Results}

Table 6 reports size-wise regression results. $\mathrm{CCC}$ has a negative relationship with firms' performance in medium and large firms however insignificant. WCME is further investigated by regressing firms' performance separately with ITDs, RTDs and PTDs. Regression results show inefficiency in working capital by Pakistani corporate sector in terms of payment to suppliers as evident from a significant negative relationship of PTDs with firms' performance in medium and large firms (which constitutes around $70 \%$ of the sample size). Inventory is being efficiently utilized only by small firms as indicated by a negative relationship of ITDs with RoA significant at $10 \%$. These results suggest an important role of WCME in determining firms' performance. The main reason of negative relation between PTDs and profitability seems to be forced maintenance of high current ratio because of State Bank's (Central bank) rules. Large firms being able to negotiate better terms with their suppliers and get longer credit periods are still struggling to improve their PTDs. These findings are supported by Chong and Hwang (2015) that high-risk borrowing firms and firms with a greater cash flow are more likely to use trade credit in lieu of short-term financing.

Table 6: Regression Results

\begin{tabular}{llcccc}
\hline Variables & Size & Coefficient & Standard Error & t-Statistic & Prob. \\
\hline C & Small & 3.690 & 1.121 & 3.293 & 0.001 \\
& Medium & 7.432 & 0.780 & 9.529 & 0.000 \\
& Large & 15.173 & 1.471 & 10.312 & 0.000 \\
\hline MC & Small & 0.001 & 0.002 & 0.497 & 0.619 \\
& Medium & 0.009 & 0.005 & 1.606 & 0.109 \\
& Large & 0.008 & 0.006 & 1.348 & 0.178 \\
\hline CCC & Small & 0.014 & 0.012 & 1.148 & 0.251 \\
& Medium & -0.002 & 0.008 & -0.181 & 0.857 \\
& Large & -0.002 & 0.009 & -.174 & 0.862 \\
\hline ITDs & Small & -0.020 & 0.011 & -1.790 & 0.074 \\
& Medium & 0.015 & 0.010 & 1.550 & 0.122 \\
& Large & -0.002 & 0.003 & -0.831 & 0.407 \\
\hline RTDs & Small & -0.012 & 0.014 & -0.805 & 0.421 \\
& Medium & 0.001 & 0.012 & -0.027 & 0.979 \\
& Large & 0.003 & 0.013 & 0.234 & 0.815 \\
\hline PTDs & Small & 0.005 & 0.012 & 0.382 & 0.703 \\
& Medium & -0.180 & 0.009 & -2.087 & 0.037 \\
& Large & -0.038 & 0.012 & -3.071 & 0.002
\end{tabular}




\begin{tabular}{llllll}
\multirow{3}{*}{ SG } & Small & 1.334 & 0.923 & 1.445 & 0.149 \\
& Medium & 0.883 & 0.646 & 1.367 & 0.172 \\
& Large & 0.615 & 1.303 & 0.472 & 0.637 \\
\hline
\end{tabular}

4.5 Ratio Analysis

Table 7 summarizes good and weak performing firms comparing average RoA for each firm with its respective IA. Firms with return on assets equal to or more than IA are considered as good performing firms and less than IA or negative (even if it is more than IA), as weak performing firms.

Table 7: Firms' Performance

\begin{tabular}{lcccccc}
\hline $\begin{array}{l}\text { Data } \\
\text { Segment }\end{array}$ & $\begin{array}{c}\text { Good performing } \\
\text { firms } \\
\text { Number }\end{array}$ & $\%$ & \multicolumn{2}{c}{$\begin{array}{c}\text { Weak Performing } \\
\text { Firms }\end{array}$} & \multicolumn{2}{c}{ Total firms } \\
& Number & $\%$ & Number & $\%$ \\
\hline Small firms & 16 & 35 & 30 & 65 & 46 & 100 \\
Medium firms & 30 & 49 & 31 & 51 & 46 & 100 \\
Large firms & 31 & 67 & 15 & 33 & 46 & 100 \\
Total firms & 77 & 50.33 & 76 & 49.67 & 153 & 100
\end{tabular}

Table 7 reports $50.33 \%$ good performing firms and $49.67 \%$ weak performing firms. The performance of large firms is highest with $67 \%$ good performing ratio as compared to $49 \%$ for medium and $35 \%$ for small firms showing a positive relationship between firms' size and performance. This supports our hypothesis 1 that 'There is a positive relationship between firms' size and performance'.

The study uses CCC as a comprehensive proxy of WCME. Average CCC of each firm for the sample period is compared with IA. All firms maintaining average cash conversion cycles less than IA are considered to be managing their working capital efficiently. Firms having average cash conversion cycles equal to or more than IA are considered to be managing their working capital inefficiently. Comparing profitability and CCC with IA is in line with that used by Singh (2011). Table 8 reports, classification of efficient and non efficient firms on the basis of working capital utilization.

Table 8: Efficiency-wise Distribution of Firms

\begin{tabular}{lcccccc}
\hline Segmentation & \multicolumn{2}{c}{ Efficient firms } & \multicolumn{2}{c}{ Non efficient firms } & \multicolumn{2}{c}{ Total } \\
& Number & \% & Number & \% & Number & $\%$ \\
\hline Small firms & 17 & 37 & 29 & 63 & 46 & 100 \\
Medium firms & 13 & 21 & 48 & 79 & 61 & 100 \\
Large firms & 9 & 20 & 37 & 80 & 46 & 100 \\
All firms & 39 & 25 & 114 & 75 & 153 & 100 \\
\hline
\end{tabular}

\section{Conclusions}

We investigated the impact of size on WCME along with variations in firms' performances (because of this impact) using ratio, descriptive, correlation and regression analyses. Results show that performance-wise large firms are better whereas WCMEwise small and medium firms are better. These findings indicate that better performance of large firms is not because of efficient utilization of working capital - rather it may be 
due to some other factors and these firms can further improve their performance if working capital is managed more efficiently. Overall Pakistani corporate sector is highly inefficient in utilizing working capital. This aspect is perhaps influenced by the presence of sizable number of large firms (which are inherently less efficient in WCM) in the sample size.

CCC has a negative but insignificant relationship with firms' performance in medium and large firms. Regression results show inefficiency in working capital by Pakistani corporate sector in terms of payment to suppliers as evident from a significant negative relationship of PTDs with firms' performance in medium and large firms (which constitutes around $70 \%$ of the sample size). Inventory is being efficiently utilized only by small firms as indicated by a negative relationship of ITDs with RoA significant at $10 \%$. These results suggest an important role of WCME in determining firms' performance. The main reason of negative relationship between PTDs and profitability seems to be forced maintenance of high current ratio because of State Bank's rules. Large firms being able to negotiate better terms with their suppliers and get longer credit periods are still struggling to improve their PTDs.

These findings lead to a two-way learning process among small, medium and large firms. Small and medium firms can learn from large firms about how to maximize their value - while large firms can learn from small and medium firms about how to improve their WCME. Future research is recommended to find out ways for small and medium firms to maximize their value and large firms to improve their WCME.

\section{References}

Chong, B. \& Hwang, I. D. (2015). Credit Ratings and Short-term Debt Financing: An Empirical Analysis of Listed Firms in Korea, Asia-Pacific Journal of Financial Studies, 44, 88-128

Connor, G. \& Sehgal S, (2001). Tests of the Fama and French Model in India, Discussion paper, 379, London UK.

Dalbor, M. C., Kim, A. \& Upneja, A. (2004). An Initial Investigation of Firm Size and Debt Use by Small Restaurant Firms, The Journal of Hospitality Financial Management, 12(1), 41-48

Deloof, M. (2003). Does Working Capital Management Affect Profitability of Belgian Firms? Journal of Business Finance and Accounting, 30: 573-587

Du, J. \& Girma, S. (2009). Source of Finance, Growth and Firm Size Evidence from China, United Nation University Research Paper No. 2009/03: 1-34

Emery, G. W. (1987). An Optimal Financial Response to Variable Demand, Journal of Financial and Quantitative Analysis, 22, 209-225

Fama, E. F. \& French, K. R. (1992). The Cross-Section of Expected Stock Returns, The Journal of Finance, 47(2): 427-465

Gentry, J. A., Vaidyanathan, R. \& Lee, H. W. (1990). Weighted Cash Conversion Cycle, Financial Management, 19 (1), 90-99

Jensen, M.C. \& Meckling, W. H. (1976). Theory of the Firm, Managerial Behavior, Agency Costs and Ownership Structures, Journal of Financial Economics, 3(4), 305-360 
Majumdar, S. K. (1997). The Impact of Size and Age on Firm-Level Performance: Some Evidence from India, Review of Industrial Organization, (12), 231-241

Myers, S. C. \& Mailuf, N. S. (1984). Corporate Financing and Investment Decisions, When Firms Have Information That Investors Do Not Have, Journal of Financial Economics, (13), 187-221

Nielson, J. (2002). Trade Credit and The Bank Lending Channel, Journal of Money, Credit and Banking, (34), 226-253

Ogundipe, S. E., Idowu, A. \& Ogundipe, L. O. (2012). Working Capital Management, Firms' Performance and Market Valuation in Nigeria, International Journal of Social, Education, Economics and Management Engineering, (6), 19-23

Park, C. \& Gladson, J. W. (1963). Working Capital, $1^{\text {st }}$ edition, Collier Macmillan Ltd, New York

Park, R. E. (1966). Estimation with heteroscedastic error terms, Econometrica, (34), 888.

Richards, V. D. \& Laughlin, E. J. (1980). A Cash Conversion Cycle Approach to Liquidity Analysis, Financial Management, 9 (1), 32-38

Robert, O'Brien, M. (2007). A Caution Regarding Rules of Thumb for Variance Inflation Factors, Quality \& Quantity, (41), 673-690

Singh, D. P. (2011). Net Working Capital Level and Return on Capital Employed in Firms of Cement Industries in India, VSRD International Journal of Business \& Management Research, 1(4), 269-280

Smith, K.V. (1973). State of the art of working capital management, Financial Management, 2 (3), 50-55

Teruel, P. J. G. \& Solano, P. M. (2007). Effects of working capital management on SME profitability, International Journal of Managerial Finance, 3 (2), 164 - 177

Zaremba, A. \& Konieczka, P. (2015). Are Value, Size and Momentum Premiums in CEE Emerging Markets Only Illusionary? Finance a úvěr-Czech Journal of Economics and Finance, 65 (1), 84-104 